\title{
A SZUPERÉRZÉKENYSÉG ÉS A VIZSGASZORONGÁS KAPCSOLATA EGY SZABOLCS-SZATMÁR-BEREG MEGYEI GIMNÁZIUMBAN VÉGZETT FELMÉRÉS ALAPJÁN
}

Szerző:

Ware Anna Julia $\uparrow$

\section{Lektorok:}

Kovács Karolina Eszter (PhD.)

Debreceni Egyetem (Magyarország)

Illés Amanda (PhD.)

Debreceni Egyetem (Magyarország)

...és további két anonim lektor

Ware Anna Julia (2021): A szuperérzékenység és a vizsgaszorongás kapcsolata egy Szabolcs-Szatmár-Bereg megyei gimnáziumban végzett felmérés alapján. Különleges Bánásmód, 7. (4). 45-53. DOI $\underline{10.18458 / K B .2021 .4 .45}$

\begin{abstract}
Absztrakt
Jelen tanulmány a szuperérzékenység és a vizsgaszorongás közötti kapcsolat vizsgálatára fókuszál. A téma aktualitását az adja, hogy a szuperérzékenység, mint személyiségvonás magyarországi viszonylatban (főleg a szuperérzékeny gyerekek különleges bánásmódra való igényét illetően) kevéssé vizsgált terület, míg külföldön egyre több kutatás jelenik meg a témában. A vizsgálat arra keresi a választ, hogy a magasabb érzékenység együtt jár-e magasabb vizsgaszorongás-szinttel. Minta: 133 fő (jellemzőik: $\mathrm{M}_{\mathrm{kor}}=15.3$; nemi eloszlás 25,56\% fiú, 74,44\% lány; évfolyambeli eloszlás 9. osztály 78,95 \% 10. osztály 21,05\%). Módszer: online és anonim módon kitölthető kérdőívcsomag három kérdőívvel. A demográfiai jellemzốk felvételéhez önállóan összeállitott demográfiai kérdőív alkalmazására került sor, a szorongás vizsgálatához a TAI-H (Sipos, Sipos \& Spielberger, 1988), az érzékenység vizsgálatához a HSPS-H (Aron, 1999, ford. Komjáthy, 2011; Pluess, 2013) került felhasználásra. Eredmény: az érzékenyebb diákoknak szignifikánsan magasabb a vizsgaszorongás-szintjük kevésbé érzékeny társaikéhoz képest. Következtetés: a pedagógiai gyakorlatban érdemes figyelembe venni a tanulók érzékenységét, hiszen sok egyéb tényező mellett ez a veleszületett jellemvonás befolyásolhatja a vizsgaszorongás-szintet és így a teljesítményt.
\end{abstract}

Kulcsszavak: szuperérzékenység, érzékenység, hiperszenzitivitás, vizsgaszorongás, differenciálás, TAIH, HSPS, HSPS-H

Diszciplina: pedagógia, pszichológia

\begin{abstract}
THE RELATIONSHIP BETWEEN HIGH SENSITIVITY AND TEST ANXIETY ON THE BASIS OF A SURVEY CARRIED OUT IN SZABOLCS-SZATMÁR-BEREG COUNTY GYMNASIUM

This article pertains to the relation between high sensitivity and test anxiety. The timeliness of this study comes from the observation that although more and more research is being conducted on high sensitivity abroad, high sensitivity as a character trait has not been researched in Hungary, especially in relation to the special treatment highly sensitive children may require. In this study, the main research question is whether a higher level of sensitivity correlates positively with a higher level of test anxiety. Sample: 133
\end{abstract}


persons (attributes: $\mathrm{M}_{\text {age }}=15.3$; gender distribution $25.56 \%$ boys, $74.44 \%$ girls; grade distribution $78.95 \%$ $9^{\text {th }}$ grade, $21.05 \% 10^{\text {th }}$ grade). Method: a questionnaire package completable anonymously online made up of 3 questionnaires. The questionnaires used were a self-constructed demographic questionnaire, the TAIH questionnaire to measure test anxiety (Sipos, Sipos \& Spielberger, 1988), and the HSPS-H questionnaire to measure sensitivity (Aron, 1999, transl. Komjáthy, 2011; Pluess, 2013). Results: students showing a higher level of sensitivity show significantly higher test anxiety levels than their less-sensitive peers. Conclusions: considering that (alongside multiple other factors) the given character trait of high sensitivity can influence test anxiety levels and conclusively also performance, it would be advisable to take students' sensitivity into account in teaching practice.

Keywords: high sensitivity, sensitivity, hypersensitivity, test anxiety, differentiation, TAI-H, HSPS, HSPS-H

Disciplines: pedagogy, psychology

Érzékenynek lenni egyszerre lehetőség és kihívás - ez minden, magát érzékenyebbnek tartó embernek ismerős gondolat lehet. Azonban annak meghatározása, hogy pontosan miben segít és gátol az érzékenység, olyan feladat, ami már kutatómunkát igényel. Ennek megfelelően született meg a szuperérzékenység fogalma, amely több vizsgálat alapján a társadalom hozzávetőleg 20-30\%-ára lehet jellemzô (Aron, 1999; ford. Komjáthy, 2011). A szuperérzékenység mint személyiségvonás feltehe-tően az egész személyiség múködésére kihat, így különböző színtereken mutatkozhat meg, úgymint a család, a munkahely, illetve gyerekek esetében az iskola. A szuperérzékenység azonban Magyarországon kevéssé kutatott, így ez a tanulmány magyarországi viszonylatban új perspektívát nyújthat a különleges bánásmódot igénylő tanulók felismerésében.

A szuperérzékenység és a vizsgaszorongás rövid bemutatását követően annak a kérdésnek a vizsgálatára és bemutatására kerül sor, hogy a szuperérzékeny gyerekekre jellemzőbb-e a vizsgaszorongás, mint nem szuperérzékeny társaikra. A kérdés megválaszolása után szó esik arról is, hogy mit lehet annak érdekében tenni, hogy a differenciálás különböző technikáit alkalmazva hogyan lehetne úgy különleges bánásmódban részesíteni az érzékenyebb gyerekeket, hogy a lehetô legjobb fejlődési közeget tudják számukra biztosítani a pedagógusok és az iskola.

\section{A szuperérzékenység fogalma és jellemzői}

A szuperérzékenység fogalma egy viszonylag új fogalom a pszichológiai szakirodalomban. Használatosak még a szuperérzékenységen kívül a magas érzékenység, hiperérzékenység, hiperszenzitivitás, túlérzékenység kifejezések is.

Egyes források a szuperérzékenységet egyenlővé teszik a hiperszenzitivitással avagy túlérzékenységgel (Nagy, 2017). Más források azonban különbséget tesznek a magas érzékenység, avagy szuperérzékenység (high sensitivity), illetve a hiperszenzitivitás, avagy túlérzékenység között (Aron, 1999, ford. Komjáthy, 2011; Smith, 2014; Mörk, 2019). Míg a szuperérzékenység egy veleszületett tulajdonság, ami miatt a szuperérzékeny egyén nehezebben szűri ki az ôt érő ingereket és érzékenyebben is reagál rájuk, addig a hiperszenzitivitás egy olyan viselkedési mintázat, megküzdési stílus, amelynél a túlérzékeny illető túlreagálja az őt érő hatásokat, tipikusan sértődékeny (Smith, 2014; Mörk, 2019).

E különbségtétel miatt ebben a tanulmányban innentől a szuperérzékenység fogalma szerepel. 
A szuperérzékenyek többek között a következô tulajdonságokkal jellemezhetók (Nagy, 2017):

- „gazdag és komplex belső világuk van,

- erôsen érdeklődnek a múvészetek és a zene iránt,

- könnyen elárasztják őket az érzelmeik,

- közönség előtt, vagy ha figyelik őket, gyengén teljesítenek,

- könnyen megijednek,

- érzékenyen reagálnak a fájdalomra, éhség érzetre és a koffeinre,

- testből érkező ingerekre különösen érzékenyek,

- akár egészen finom érzékelésbeli változásokat is képesek felismerni."

Ezek alapján elmondható, hogy a szuperérzékenyek az őket érő, a külvilágból és saját testükből érkező ingekre fokozottan érzékenynek (Nagy, 2017; Mörk, 2019). Ezen és az itt fel nem sorolt tulajdonságok eltérő mértékben lehetnek jelen a szuperérzékeny embereknél, nincs két egyforma módon szuperérzékeny ember (Aron, 1999, ford. Komjáthy, 2011). Ezeknek a jellemzőknek a magyarázata az agyi múködésben, ezen belül az ingerfeldolgozásban található meg - a tudományban a szuperérzékenységet szenzoros feldolgozási érzékenységnek (sensory processing sensitivity) is nevezik (Aron \& Aron 2018).

Itt fontos megjegyezni, hogy a szenzoros feldolgozási szenzitivitás nem azonos a szenzoros feldolgozási vagy szenzoros integrációs zavarral. A szuperérzékenyek egész egyszerűen másképp dolgozzák fel az ôket érő ingereket: kevésbé érzékeny társaikhoz képest alacsonyabb az érzékelési küszöbük, ́́gy ami társaiknál optimális arousal-szintet idéz elő, a szuperérzékenyeknél már túlingerelt állapothoz és így transzmarginális inhibícióhoz vezethet (Aron, 1999, ford. Komjáthy, 2011).

\section{A vizsgaszorongás fogalma}

A fokozott izgalmi állapot nem törvényszerúen jár együtt félelemérzettel, azonban ez nem jelenti azt, hogy egyáltalán nem járhat együtt félelemérzettel vagy a szorongással és annak különböző jeleivel, tüneteivel (Aron 1999, ford. Komjáthy 2011). Ezen okból ebben a részben röviden bemutatásra kerül a szorongás, azon belül a vizsgaszorongás.

$\mathrm{Az}$ emberi élet során minden egyén találkozik valahol, valamikor a szorongással, így az iskoláskorú gyerekek életének is része. A szorongás formáit különböző tényezők mentén lehet csoportosítani, mint például normalitás/kórosság, facilitáló/debilizáló, állapot- vagy vonásszorongás (Mező, 2011; Nótin, 2015)

A szorongás az aktivációs szint változásaihoz köthető. Ebben nyilvánul meg a szerepe a teljesítménnyel kapcsolatban, mivel a feladatok sikeres teljesítéséhez optimális aktivációs szint szükséges, túl alacsony vagy túl magas aktivációs szint esetén nem valósul meg az optimális feladatteljesítés. A szorongás így lehet facilitáló is, ,jellemzően a közepes mértékú (...) izgalom serkenti a teljesítményt" (Nótin, 2015, 30. o.).

Túl magas arousal-szint esetén gátlás (más néven transzmarginális inhibíció) következik be, megjelenhet a debilizáló szorongás, így alulteljesítéshez vezethet (Mezó, 2011; Nótin, 2015). Ezt hivatott szemléltetni az arousal-szinthez kapcsolódva az 1. ábra.

Megjegyzendő, hogy a túl magas arousal-szintből következő gátlás és a szorongás megléte nem okoz automa-tikusan alulteljesítést; az alulteljesítésben sok egyéb, egymással interakcióba lépő tényező is kifejti hatását.

A teljesítmény kapcsán máris elérkeztünk a szorongáson belül az iskolai szorongás különböző formáihoz.

Cassady (2010, idézi Nótin, 2015, 30.o.) alapján az iskolai szorongásnak három nagy típusa van:

„(1) Kontextustól független szorongás, azaz nem specifikusan iskolai szorongásformák

(2) Kontextustól függő iskolai szorongásformák

(3) Tartalomtól függő, azaz tantárgyi szorongásformák." 
1. ábra: Az arousal-szint hatása a teljesitményre (forrás: Kovács, 2013, 15. o.)

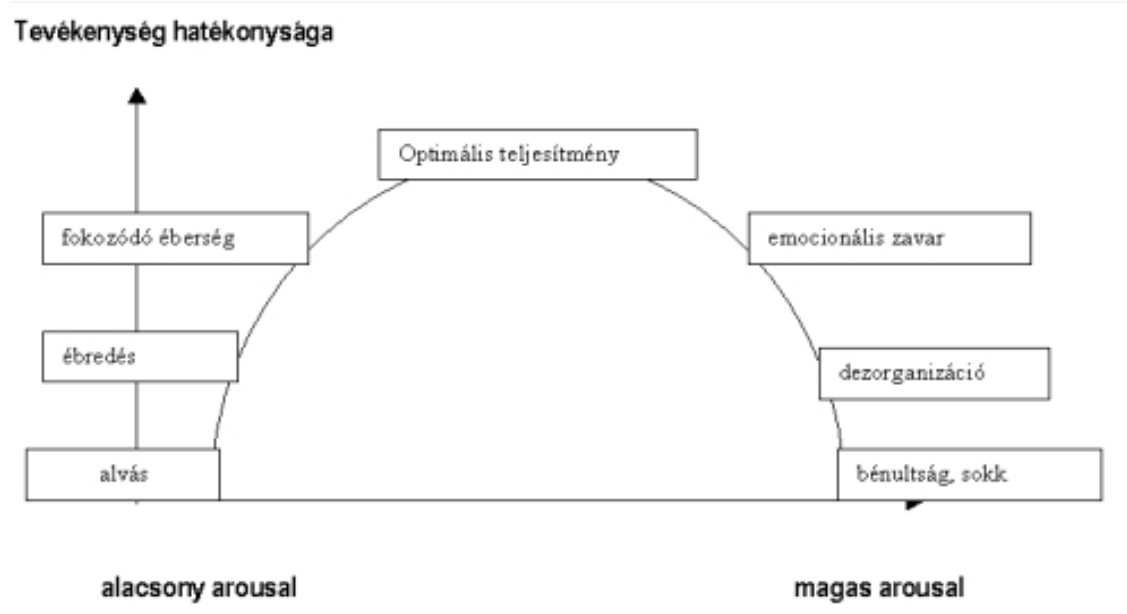

Ezen típusokból a vizsgaszorongás a kontextustól függő iskolai szorongásformák csoportjába tartozik. A vizsgaszorongásra többféle definíció is létezik, melyek közül több is a kognitív folyamatokra koncentrál elsősorban. A vizsgaszorongás azonban „nem tekinthető egy időben jól körülhatárolható eseménynek, sokkal inkább egy tanulásteljesítés folyamatban jelentkező eseménysorozatnak", melynek különböző beavatkozási formákat igénylő típusai vannak (Nótin, 2015, 38. o.).

\section{Módszer}

Az optimális teljesítmény eléréséhez optimális aktivációs szint szükséges, és a túl magas aktivációs szint vizsgaszorongás formájában is megjelenhet. Ennek megfelelően jelen kutatás fókuszát a szuperérzékeny gyermekek vizsgaszorongás-szintjének vizsgálata képezi. A szuperérzékeny emberek optimális aktivációs szintje alacsonyabb, mint társaiké (Nagy, 2017), így feltételezhető, hogy vizsgahelyzetekben a szuperérzékeny embereknek magasabb a vizsgaszorongás szintje, mint társaiké. Ezen feltételezésnek további alátámasztást ad, hogy a szuperérzékenyekre jellemző lehet az a tulajdon-ság, hogy ha figyelik őket egy feladat teljesítése vagy vizsga közben, annyira szoronghatnak ettől, hogy rosszabbul teljesítenek. Ez a tulajdonság oly mér-tékben jellemző lehet, hogy a szuperérzékenységet felmérő tesztek külön részét képezik az erre vonatkozó itemek (Aron, 1999, ford. Komjáthy, 2011).

Így ennek a vizsgálatnak központi, kutatási kérdése, hogy a szuperérzékenység-skálán elért magasabb pontszám pozitívan korrelál-e a vizsgaszorongás-skálán elért magasabb pontszámmal. Ennek megfelelően a hipotézis arra irányul, hogy mivel az érzékenyebb egyéneknek (gyerekeknek) alacsonyabb az ingerérzékelési küszöbük és az optimális aktivációs szintjük társaikénál, ezért dolgozatírás, felelés vagy egyéb vizsgahelyzetek közben átlagosan magasabb lesz a vizsgaszorongás-szintjük, mint kevésbé érzékeny társaikénál (Aron, 1999, ford. Komjáthy, 2011; Nótin, 2015).

\section{Minta}

A vizsgálati minta randomizáláson alapult. Mivel jelen kutatás célját nem képezte a reprezentativitás elérése, így a vizsgálati minta nem reprezentatív.

A vizsgálatban egy nyíregyházi gimnázium 9-10. osztályos tanulói vettek részt $(n=139$ fó). A vizsgálatból hat személy került kizárásra, így összesen 133 tanuló eredményei kerültek elem- 
zésre. Egy tanuló esetében a szülői hozzájárulás nem adatott meg, így a tanuló kizárásra került. A további öt kizárt tanuló valótlan adatok megadásáért került kizárásra: egy tanuló az évfolyamának a 13. évfolyamot jelölte meg, míg az adott középiskolában nincsen 13. évfolyam, a másik négy pedig iskolája telephelyének a fôvvárost adta meg, ami egy nyíregyházi középiskola esetén szintén nem felel meg a valóságnak.

A tanulók 79\%-a 9., 21\%-a pedig a 10 . évfolyamról került ki, átlagéletkoruk 15,3 év ( $S D=$ .52). A nemek arányát tekintve a lányok voltak többségben a kitöltők 74,44\%-át képezve. A szuperérzékenységgel kapcsolatos korábbi kutatásokban megmutatkozott, hogy nemtől független magának a szuperérzékenységnek mint tulajdonságnak a megjelenése, bár társadalmilag fiúknál, férfiaknál talán kevésbé elfogadott ( Aron, 1999, ford. Komjáthy, 2011).

A kutatásban a lányok magas aránya nem a téma jellegével, hanem az adott iskola jellemzőjével magyarázható: az adott gim-náziumban hosszú évek óta megközelítőleg 3:1 a lány és fiú tanulók aránya.

A szubjektív és az objektív anyagi helyzetre adott válaszokat megnézve megállapítható, hogy a vizsgálatban részt vevô gyerekek egyetlen kivétellel átlagos vagy az átlagosnál jobb anyagi helyzetû családból származnak, mint ez a 2. ábrán is látható.

\section{Eszköz}

A vizsgálathoz egy kérdőívcsomag került felhasználásra, amely egy demográfiai kérdőívből, a TAI-H-ból és a HSPS-ból állt.

A demográfiai kérdôív a személy adataira és az iskola adataira kérdezett rá. A személyhez köthető adatok közül a következők kerültek felvételre: nem, életkor, az állandó lakhely típusa, a tanév közbeni lakhely, a szülők iskolai végzettsége, illetve a szubjektív és az objektív anyagi helyzet. Az iskolához kapcsolódó adatok közül rögzítésre került a kutatásban részt vevő tanuló évfolyama, a középiskola típusa, települése és fenntartója.

\section{2. ábra: A viæsgálati minta eloszlása squbjektív anyagi} belyzet szerint (forrás: a szerzó)

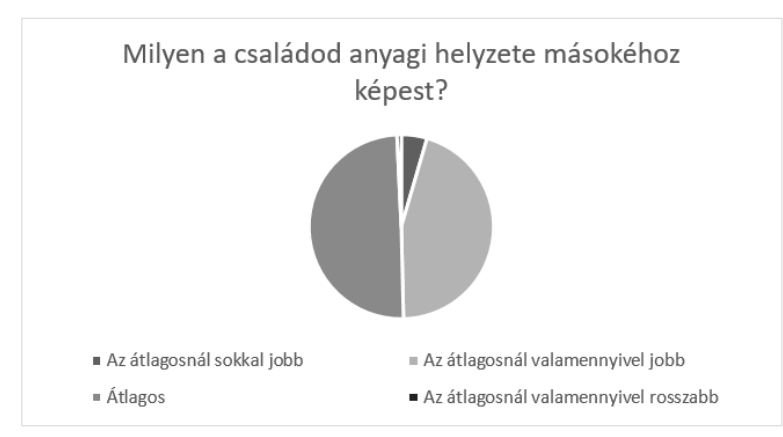

A TAI-H (Test Anxiety Inventory, azaz vizsgaszorongás kérdőív) módosítás nélkül került alkalmazásra, mivel ugyanazt a célt szolgálja, mint jelen vizsgálat, azaz az iskoláskorú gyermekeknél a vizsgaszorongás mértékének felmérését. A felhasznált kérdőív általános iskolás gyerekek vizsgálatára került kidolgozásra, azonban mivel lényegi eltérés nincsen a középiskolások vizsgálatára használat kérdőív között (Nótin, 2015), ezért az eredeti kérdőív került bele a kérdőívcsomagba. A kérdőív 20 itemből áll, melyekkel a gyerekek a vizsgahelyzetekkel, feleléssel, dolgozatírással kapcsolatos állításokkal jellemezhetik magukat egy egytôl négyig tartó skálán (1 - szinte soha, 2 -néha, 3 - gyakran, 4 - mindig), így mérve a vizsgaszorongás szintjét (Sipos , Sipos \& Spielberger, 1988). A TAI-H reliabilitása: $\alpha=0,921$. A TAI-H skála két alskálát tartalmaz, úgymint aggodalom (W) és emocionális izgalom (E); ezek az alskálák ebben a vizsgálatban nem kerültek külön-külön kiértékelésre. Továbbá a vizsgálat során a szorongás és érzékenység közötti kapcsolat feltérképezésére fókuszáltunk, így csoportbontásra nem került sor e két változó alapján.

A HSPS-H (Highly Sensitive Person Scale, azaz szuperérzékenység-skála) az ebben a vizsgálatban 
alkalmazott formájában újdonság, mivel kutatásra alkalmas magyar változat eddig nem jelent meg. A skála két forrás felhasználásával készült, mintegy ötvözve a kettőt. A HSPS-H egyik alapja egy, a szuperérzékenység kutatására alkalmas, az eredeti kérdőívhez képest rövidebb (12 itemes), angol nyelvú változat (Pluess 2013), amely azért került felhasználásra, mert az itemeket 1-tól 7-ig tartó Likert-skálán jelöli (1 - egyáltalán nem, 4 közepesen, 7 - nagyon). Az eredeti angol nyelvú kérdőív 27 itemet tartalmaz, reliabilitása $\alpha=0,86$ (Aron és Aron, 1997).

Másik alapja egy magyarul megjelent, laikusoknak szóló skála, ami ugyanazt a 27 itemet tartalmazza magyarul, mint az eredeti, kutatásra alkalmas angol nyelvű kérdőív (Aron, 1999, ford. Komjáthy, 2011). Azonban az itemeket igaz-hamis módon jelöli, így kutatásra nem alkalmas, viszont maguk a magyar nyelvre lefordított itemek nagyon is jól felhasználhatóak egy ilyen jellegú kutatáshoz.

Az ily módon megalkotott HSPS-H reliabilitása: $\alpha=0,768$.

\section{Eljárás}

$\mathrm{Az}$ „Eszközök” alpontban részletezett kérdőíveket online és anonim módon lehetett kitölteni. A kérdőívcsomag kitöltését bármikor meg lehetett szakítani következmények nélkül, és a kutatással, kérdőívvel kapcsolatban felmerülő kérdések esetleges megjelenése miatt a kérdőív elején szerepel egy kapcsolattartási e-mail cím. A vizsgálat menetét leíró, a kérdőívcsomag elején megjelenő tájékoztatás és a vizsgálatba a megadott feltételek szerinti beleegyezés megadása után a kitöltő a fent részletezett kérdőívekkel találkozhatott az előző alpontban szereplő sorrendben. A kérdőívcsomag kiskorúak számára készült, így a kutatásban való részvétel feltételeihez tartozott a szülői beleegyezés megléte. Ezt ellenőrizni egy, a kérdőívcsomag elején szereplő eldöntendő kérdés volt hivatott; nemleges válasz esetén a kérdőív kitöltése még bármely ezen kívüli adat felvétele előtt megszakadt.
A kérdőívek kitöltése megközelítőleg 10 percet vett igénybe.

A kapott eredmények Excel táblázat formájában kerültek rögzítésre; ezt követően SPSS-ben történt a TAI-H és HSPS-H kérdőívek, valamint egyéb adatok statisztikai elemzése.

\section{Eredmények}

A TAI-H és a HSPS-H átlagpontszámai: $M_{T A I}$ ${ }_{H}=43,8$ pont, $S D=12,69 ; M_{H S P S-H}=4,29$ pont, $S D=0,94$. A Kolmogorov-Smirnov normalitásvizsgálat alapján a TAI-H-ra adott válaszok nem normális eloszlást, a HSPS-H-ra adott válaszok normális eloszlást mutattak, így a változók közötti kapcsolat megállapítására nem paraméteres próbára került sor. A Spearman-féle rangkorreláció alapján a két változó, vagyis a vizsgaszorongás és a szuperérzékenység között közepesen erôs pozitív kapcsolat áll fenn $(r=0,474, \quad p<0,001)$, így beigazolódott az a fentebb leírt hipotézis, miszerint a szuperérzékeny gyerekeknek átlagosan magasabb a vizsgaszorongásszintjük kevésbé érzékeny társaikhoz képest.

Annak megállapítására, hogy ténylegesen az eleve adott magasabb érzékenységi szint állhat-e a magasabb vizsgaszorongás-szint hátterében, a lineáris regresszió lefolytatása is a statisztikai elemzés részét képezte. Igazolást nyert az a feltételezés is, miszerint a magasabb érzékenység-szint határozza meg a magasabb vizsgaszorongás-szintet és nem fordítva, hiszen a lineáris regresszió ebben a tekintetben szignifikáns eredményt mutat (Beta $=0,495$, $p<0,001)$.

A felvett demográfiai adatok birtokában lehetőség nyilt további elemzésekre is a csoportok közötti összehasonlításokhoz egyszempontos varianciaanalízis (one-way ANOVA) alkalmazva.

A nem tekintetében a vizsgaszorongás és az érzékeny tekintetében is szignifikáns különbség mutatható ki (TAI-H: $d f=1, F=12,770, p<0,001$; HSPS-H: $\quad d f=1, \quad F=9,876, \quad p<0,05) . \quad$ A lányok esetében az átlagpontszámok $M_{T A I H-H}=46,03$, 
$M_{H S P S-H}=4,44$, a fiúknál $M_{T A I H-H}=37,38, \quad M_{H S P S-}$ ${ }_{H}=3,87$.

Az életkor alapján egyik mért változóban sem áll fenn szignifikáns különbség (TAI-H: $d f=3, F=2,48$, $p>0,05$; HSPS-H: $d f=3, \mathrm{~F}=2,628, p>0,05)$.

A szubjektív anyagi helyzet alapján a TAI-H-n elért pontszámban szignifikáns különbség áll fenn $(d f=3, \quad F=4,125, \quad p<0,05) . \quad$ A csoportok átlagpontszámai a következőképpen alakultak: az átlagosnál valamennyivel rosszabb anyagi helyzet: $M_{T A I H-H}=56$; átlagos anyagi helyzet: $M_{T A I H-H}=45,74$; az átlagosnál valamennyivel jobb anyagi helyzet: $M_{\text {TAIH-H }}=40,48$; az átlagosnál sokkal jobb anyagi helyzet: $M_{T A I H-H}=55,67$. A HSPS-H átlagpontszámának esetében azonban nem szignifikáns az eltérés $(d f=3, F=2,646, p>0,05)$.

\section{Megvitatás}

Mint az eredmények bemutatásában is látszik, a szuperérzékenység és a vizsgaszorongás között szignifikáns pozitív kapcsolat áll fenn, így beigazolódott az a feltételezés, hogy a szuperérzékenység magasabb vizsgaszorongás-szinttel jár együtt. A kapott eredményeket látva ismét megfogalmazódik, hogy bár Magyarországon a szuperérzékenység kevéssé kutatott, fontos lenne vizsgálni ezt a vonást. Azt tekintve, hogy a HSPS-H először került alkalmazásra ebben a kutatásra alkalmas formában magyar nyelven, a további kutatások témájaként szerepelhet a HSPS-H nagyobb elemszámú mintán történő alkalmazása felnőtteknél és gyermekeknél egyaránt, akár az eredeti, hosszabb kérdőív további elemeinek magyar fordításával is kibővítve, hogy a szuperérzékenység magyarországi kutatása is elindulhasson.

\section{Korlátozások}

A vizsgálat egyik korlátozása a kis elemszámú, nem reprezentatív minta. Emiatt a későbbiekben érdemes lenne a vizsgálatot nagyobb és komplexebb mintán elvégezni.
Egy másik korlátozás a HSPS-H kérdőív újszerúsége. Mivel a HSPS-H nem szerepelt korábban kutatásban, ezért nem validált kérdőívről van szó. A kérdôív szélesebb körű alkalmazásának érdekében fontos feladat lehetne a nagyobb, reprezentatív mintán történő validálás.

További korlátozás, hogy a HSPS-H kérdőív alkalmazásánál nem történt negatív affektivitásra való kontroll annak ellenére, hogy a szuperérzékenység fó kutatói ezt javasolják (Aron \& Aron, 2018). Egy hasonló vizsgálatnál vagy a vizsgálat megismétlésekor terveim közé tartozik ennek a mulasztásnak a pótlása.

Konklúziók: a tanulmány elején megfogalmazott kérdés merül fel ismét: mit lehet annak érdekében tenni, hogy a szuperérzékeny gyerekek számára az iskola a lehetô legjobb fejlődési közeget biztosítsa? $\mathrm{Az}$ érzékenyebb gyerekek magasabb vizsgaszorongás-szintje, mint már említésre került, optimális arousal-szintjük alacsonyabb voltával függ össze (Aron, 1999, ford. Komjáthy, 2011). Az optimális arousal-szint és a szuperérzékenység pedig nagymértékben adottak, változtatni rajtuk igen nehéz. Talán úgy lehet a legjobban segíteni a szuperérzékeny gyerekeknek kevésbé szorongani vizsgahelyzetekben és így önmaguk személyes potenciálját kiaknázni, hogyha olyan változtatásokat végzünk az osztályteremben vizsgahelyzetek fennállásakor, amelyek csökkentik a beérkező környezeti ingerek mennyiségét és intenzitását és így a tanulók arousal- avagy aktivációs szintjét. A szuperérzékenyek sok esetben tehetségesek is valamely tekintetben, így még inkább indokolttá válik a különleges bánásmód alkalmazása és a szuperérzékenyek igényeihez való alkalmazkodás az osztályteremben (Aron, 1999, ford. Komjáthy, 2011).

A szuperérzékeny diákokkal való pedagógiai munkához már léteznek megfigyelések, tippek, javaslatok, melyeket a fent említett okok miatt érdemes lehet kipróbálni, alkalmazni iskolai légkör- 
ben, különös tekintettel a sokszor szorongással telített vizsgahelyzetekre.

Ezekből néhány, a vizsgaszorongás témájában releváns megjegyzés és javaslat felsorolására kerül sor Aron, 1999 nyomán (ford. Komjáthy, 2011, 283. о.):

- „A szuperérzékenyek többnyire (...) igyekeznek kihozni magukból a maximumot. Legtöbbjük igen tehetséges. Ugyanakkor túlingerelt állapotban senki sem teljesít jól, és a szuperérzékenyek könnyebben túlingerlődnek, mint mások. Minél inkább próbálkoznak, miközben figyelik őket vagy egyéb nyomás helyeződik rájuk, annál valószínúbb, hogy elbuknak, ami általában rendkívül demoralizálóan hat rájuk.” (E. Aron, 1999, ford. Komjáthy, 2011, 283. o.)

- „A fokozottan stimuláló környezet (...) hamarabb kimeríti a szuperérzékeny diákokat."

- „Ne féltsd túl a szuperérzékeny diákot. Bátran ösztönözd, hogy próbálja megtenni, ami nehezére esik. Olyan alkalmat válassz, amikor sikerrel jár."

- „Légy engedékeny a jellemvonásával kapcsolatban, mígnem a diák megfeleló (...) állóképességre tesz szert. Ha előadást kell tartania, rendezz „fôpróbát” vagy engedd meg, hogy jegyzeteket használjon vagy felolvassa azokat."

Ezen javaslatok nyomán és szellemében a következő gyakorlati tanácsok javasoltak a szuperérzékeny diákoknál, különös tekintettel a felelésre és dolgozatíratásra:

- A szuperérzékeny diákokat figyelembe véve igyekezzünk dolgozatíratás vagy feleltetés közben a környezetből érkező ingerek mennyiségét és erősségét csökkenteni, hiszen maga a vizsgahelyzet már épp eléggé nagy stresszforrást jelent egy érzékenyebb diák számára. Szellőztessük ki a termet, igyekezzünk a lehető legnagyobb csendet biztosítani, a túlzottan erôs vizuális ingereket távolítsuk el a teremből. A csend különösen fontos lehet, hiszen egy szuperérzékeny gyereket már az is zavarhatja és így ronthatja teljesítményét, hogyha körülötte lábbal dobolnak, vagy csak halkan kopogtatják az íróeszközt a padon.

- Társainál a szuperérzékeny gyerek arra is érzékenyebb, ha valamely fiziológiai igény lép fel. Ezt a gyakorlatban úgy kell elképzelni, hogy ha az érzékenyebb tanuló éhes, szomjas, vagy mosdóba kell mennie, tovább romlik a teljesítménye. Épp ezért érdemes lehet a tanúlóknak megengedni, hogy dolgozatírás vagy akár feleltetés közben (a többieket nem zavarva!) igyon néhány korty vizet, egyen pár falatot vagy kimenjen a mosdóba.

Ezek kicsi dolgoknak tûnhetnek, de sokat segithet egy érzékenyebb gyereknek az optimális arousal-szint és így teljesítmény elérésében, hogyha fiziológiai szükségletei kielégítettek.

- Vegyük figyelembe, hogy az érzékenység, bár sokszor tűnhet annak, nem feltétlenül azonos vagy jár együtt a félénkséggel. Megfelelő környezetben a szuperérzékeny egyének is igen bátrak tudnak lenni. Feleltetésnél eleinte segíthet, hogyha nem az egész osztály hallja, figyeli a feleletét, hanem csak a pedagógus, esetleg még két osztálytárs, mint a fair play tanúja. A felelésbe így bevezetve idővel hozzászoktathatjuk az egész osztály elé való kiálláshoz is (ami szintén sikerélményt biztosithat a tanulónak), de fontos, hogy ezt fokozatosan tegyük.

- Igény esetén beszélgessünk az érzékeny tanúlóval az érzékenységéről. Az önértékélés és önbizalom fejlődését, a sikerorientáltság kialakítását és a tanuló optimális teljesítményének elérését pozitív irányba befolyásolhatja, ha az érintett ismeri a szuperérzékenységgel járó előnyöket és azt a tényt, hogy annyira talán nincs is ezzel a tulajdonsággal egyedül, hiszen a társadalom megközelítőleg 20-30\%-ára jellemző ez a tulajdonság (Aron, 1999, ford. Komjáthy, 2011). 
Az itt részletezett észrevételek, javaslatok remélhetôleg segítik majd az érzékeny gyerekekkel dolgozó pedagógusok munkáját és ennek kapcsán a szuperérzékeny tanulók teljesítményének optimalizálását. A szuperérzékeny gyerekek között is számtalan egyéni különbség lehet, ezek a javaslatok csupán támpontok, de bátran tovább lehet ezeket fejleszteni, az adott tanuló egyéni igényeire szabni. Hiszen minden tanuló optimális fejlődése úgy biztosított, hogyha lehetôség szerint pontosan azt kapja, amire neki személy szerint szüksége van.

\section{Ware Anna Julia emlékére...}

A tanulmány a szerzó hozzátartozójának megjelentetési hozzájárulásával és engedélyével jelent meg.

\section{Irodalom}

Aron, Arthur, \& Aron, Elaine. (2018). Tips for SPS Research. Retrieved from: https://hsperson.com /wpcontent/uploads/2018/08/Tips_for_SPS Research Revised July24 2018.pdf (Letöltés: 2019. 04. 02.)

Aron, Aarthur, \& Aron, Elaine (1997). Sensoryprocessing sensitivity and its relation to introversion and emotionality. Journal of Personality and Social Psychology, 73(2), 345-368. doi 10.1037//0022-3514.73.2.345

Aron, Elaine (1999). Szuperérzékeny vagyok? (Komjáthy K. , ford. 2011). Budapest: Sensum. Donum. (Az eredeti mú 1999-ben jelent meg).

Aron, Elaine (1999). The Highly Sensitive Person: How to Thrive When the World Overwhelms You . kiadó: Thorsons. kiadás: New Ed.

Bányai Éva \& Varga Katalin (2013). Affektív pszichológia - az emberi késztetések és érzelmek világa. Budapest: Medicina Könyvkiadó Zrt.

Kovács Karolina Eeszter (2013). Sportolj! A sportolás hatása kiskamaszok énképére, szorongására, teljesit- ményigényére és pszichés immunkompetenciajjára (BA szakdolgozat). Debrecen: Debreceni Egyetem.

Mező Ferenc (2011). Tanulás: diagnosztitika és fejlesztés az. IPOO-modell alapján. K+F Stúdió Kft., Debrecen.

Mörk Laura (2019. március). Kik azok a szuperérzékenyek? Nök Lapja, 2019/13. 52-53. Retrieved from:

Nagy Vanda (2017 augusztus 16). Hiperszenzitivitás - avagy a túlérzékenység hatásai. Retrieved from: https://mindsetpszichologia.hu/2017/08/16/h iperszenzitivitas-avagy-a-tulerzekenyseghatasai// (Letöltés: 2019. 06. 26.)

Nótin Ágnes (2015). Iskolai szorongásformák megjelenése középiskolás tanulóknál. Doktori disszertáció. Debrecen: Debreceni Egyetem Humán Tudományok Doktori Iskola.

Pluess, M. (2013, április). Sensory-Processing Sensitivity: A potential mechanism of differential susceptibility. Elöadva: Society for $\mathrm{n}$ Child Development, Seattle, WA. Retrieved from: https://hsperson.com/wpcontent/uploads/201 8/08/Tips_for_SPS Research_Revised_July24 2018.pdf (Letöltés: 2019. 06. 30.)

Sipos Kornél, Sipos Mihály., \& Spielberger, C. D. (1988). A Test Anxiety Inventory általános iskolások vizsgálatára kidolgozott magyar változata. In Mérei F., Szakács F. (Eds.), Psæichodiagnosztikai Vademecum I/2. Budapest: Tankönyvkiadó. 123-132.

Smith, S. T. (2014 november 10). The Difference Between Highly Sensitive and Hypersensitive. Retrieved from: https://www.psychology today.com/us/blog/ironshrink/201411/thedifference-between-highly-sensitive-andhypersensitive 